\title{
Hubungan Tingkat Pengetahuan Tentang IVA Dengan Perilaku Pemeriksaan IVA
}

\section{Relationship of Knowledge Level About VIA With VIA Examination Behavior}

\author{
Sari Purwanti ${ }^{1 *}$, Sri Handayani ${ }^{2}$, dan RR Viantika Kusumasari ${ }^{3}$ \\ 1. Program Studi Ilmu Keperawatan STIKes Surya Global Yogyakarta, Indonesia \\ 2. Program Studi Ilmu Keperawatan STIKes Yogyakarta, Indonesia \\ 3. Program Studi Ilmu Keperawatan STIKes Surya Global Yogyakarta, Indonesia \\ Email Korespondensi: purwantisari367@gmail.com
}

\begin{abstract}
Abstrak
Latar belakang: Pemeriksaan IVA merupakan salah satu metode deteksi dini kanker serviks menggunakan asam cuka yang memerlukan biaya murah, praktis dan sensitifitas yang tinggi. Kesadaran wanita untuk mendeteksi gejala kanker serviks masih sangat rendah, hal ini dilihat dari cakupan pemeriksaan IVA di Puskesmas Kabupaten Bantul tahun 2018sebesar 1.3\%. Sementara itu cakupan IVA Puskesmas Bambanglipuro tahun2018 sebesar 0.13\%. Desa Sidomulyo merupakan salah satu cakupan wilayah kerja Puskesmas Bambanglipuro Bantul yang memiliki cakupan IVA terendah.

Tujuan: Untuk mengetahui hubungan tingkat pengetahuan tentang IVA dengan perilaku pemeriksaan IVA pada WUS Desa Sidomulyo Bambanglipuro Bantul.

Metode: Penelitian ini adalah penelitian deskriptif analitik dengan desaincross sectional. Populasi penelitian semua wanita usia subur yang berada di Dusun Selo Desa Sidomulyo Bambanglipuro Bantul sebesar 82 wanita usia subur. Sampel diambil secara purposive sampling terhadap 50 wanita usiasubur. Pengumpulan data menggunakan kuesioner. Analisis data menggunakan uji korelasi Kendall-Tau.

Hasil: Tingkat pengetahuan wanita usia subur mayoritas cukup yaitu 29 (58,0\%) dan perilaku pemeriksaan IVA mayoritas cukup $30(60,0 \%)$. Hasil uji korelasi kendall-tau diperoleh hasil nilai sig $0,000(<0,01)$.

Kesimpulan: Terdapat hubungan yang bermakna antara tingkat pengetahuan tentang IVA dengan perilaku pemeriksaan IVA pada WUS Desa Sidomulyo Bambanglipuro Bantul.
\end{abstract}

Kata kunci: Pemeriksaan IVA, Pengetahuan, WUS

\begin{abstract}
Background:VIA examination is one of the methods of early detection of cervical cancer using vinegar which requires low cost, practical and high sensitivity.Women's awareness to detect symptoms of cervical cancer is still very low, this can be seen from the scope of VIA examinations in Bantul District Health Center in 2018 of 1.3\%. Meanwhile the Coverage of Bambanglipuro Health Center IVA in 2018 is 0.13\%. Sidomulyo village is one of coverage areas of the Bambanglipuro Public Healt Center in Bantul, which has the lowest VIA coverage.

Objective: To determine the relationship of the level of knowledge about VIA with VIA examination behavior in WUS Sidomulyo Village Bambanglipuro Bantul.

Method: This research is descriptive analytic with cross sectional design. The study population of all women of childbearing age in the village of Selo, Sidomulyo Bambanglipuro Village, Bantul of $82 r$ women of childbearing. Samples were taken by purposive sampling of 50 women of childbearing age. Data collection using a questionnaire. Data analysis using the Kendall-Tau correlation test.
\end{abstract}


Result: The level of knowledge of the majority of women of childbearing age were sufficient (29.0\%) and the majority of VIA examinations were 30 (60.0\%). Kendall-tau correlation test results obtained sig value of $0,000(<0.01)$.

Conclusion: There is a significant relationship between the level of knowledge about VIA with VIA examination behavior in WUS Sidomulyo Village Bambanglipuro Bantul.

Keywords:Knowledge, VIA examination, WUS

\section{PENDAHULUAN}

Berdasarkan IARC (International Agency For Research On Cancer) pada tahun 2016, terdapat 14.067.894 kasus baru kanker dan 8.201.575 kematian akibat kanker diseluruh dunia. Di Asia, dilaporkan 312.990 kasus kanker serviks (59\%) dan 50\% mengalami kematian (IARC, 2016).

Kanker serviks merupakan kanker paling sering keempat pada wanita dengan perkiraan 570.000 kasus baru pada tahun 2018 dan mewakili 6,6\% dari semua kanker pada wanita. Sekitar 90\% kematian akibat kanker serviks terjadi di negara-negara berpenghasilan rendah dan menengah. Secara global, tingkat kematian yang tinggi dari kanker serviks dapat dikurangi melalui pendekatan komprehensif yang mencakup pencegahan, diagnosis dini, skrining yang efektif dan program pengobatan. ${ }^{1}$

Berdasarkan GLOBOCAN pada tahun 2018 kanker serviks menduduki urutan kedua di Indonesia dalam segi angka kejadian, dengan estimasi jumlah insiden kanker adalah 348.809 kasus, dan 32.469 kasus diantaranya merupakan insiden kanker serviks, sedangkan dalam segi tingkat mortalitas kanker seriks menduduki urutan ketiga sebagai penyebab kematian dengan menyumbangkan $10,12 \%$ yaitu 18.279 kasus, setelah kanker payudara $12,56 \%$ dan kanker paru-paru $14,44 \%$ dari jumlah estimasi insiden kanker.$^{2}$ Angka prevalensi tertinggi berada di Provinsi Daerah Istimewa Yogyakarta sebanyak 4,86 per 1000 penduduk. $^{3}$

Menurut STP RS Dinas Kesehatan DIY, jumlah kasus kanker serviks sebanyak 725 kasus rawat jalan dan 619 kasus rawat inap (Dinas Kesehatan DIY, 2018).(4) Untuk cakupan deteksi dini kanker leher rahim dengan metode IVA Kabupaten/Kota dan Puskesmas Provinsi D.I. Yogyakarta tahun 2018 didapatkan Kabupaten Kulon Progo sebanyak 1.784 wanita usia subur, Kabupaten Bantul sebanyak 1.856 wanita usia subur, Kabupaten Gunung Kidul sebanyak 814 wanita usia subur, Kabupaten Sleman sebanyak 3.831 wanita usia subur, dan Kota Yogyakarta sebanyak 2.139 wanita usia subur ${ }^{4}$

Kanker serviks menimbulkan dampak terhadap fisik, psikologis, spritual, bahkan kematian bagi penderitanya (Misgiyanto, 2014). Sementara itu, menurut data Badan Penyelenggara Jaminan Sosial (BPJS) dampak bagi negara pada tahun 2015 penderita kanker termasuk kanker serviks yang mendapatkan pengobatan telah menghabiskan biaya pengobatan/perawatan sebesar 2,29 triliun rupiah (Kemenkes RI, 2017).

Penyebab utama kanker serviks adalah human papilloma virus (HPV). Faktor risiko yang bisa menyebabkan perempuan terkena kanker serviks adalah menikah atau memulai aktivitas seksual pada usia muda (kurang dari 18 tahun), berganti-ganti pasangan seks, sering menderita infeksi di daerah kelamin, wanita yang melahirkan banyak anak, dan wanita yang merokok. ${ }^{5}$

Salah satu upaya Pemerintah Indonesia untuk menurunkan prevalensi kanker serviks tertuang dalam Keputusan Menteri Kesehatan No. 796/Menkes/SK/VII/2010 tentang pedoman teknis pengendalian kanker payudara dan kanker leher Rahim yang menjelaskan upaya pencegahan kanker serviks dapat dilakukan dengan melakukan skrining dengan metode pemeriksaan IVA. Pemeriksaan IVA memiliki kelebihan diantaranya kesederhanaan teknik, biaya rendah, dapat dilakukan di Puskesmas oleh dokter umum dan bidan dan dapat segera memberikan hasil yang dapat digunakan untuk tindakan pengobatan selanjutnya. ${ }^{6}$ 
Tes IVA adalah sebuah pemeriksaan skrining pada kanker serviks dengan menggunakan asam asetat 3-5\% (Nugroho, 2010). Berdasarkan hasil uji diagnostik, pemeriksaan IVA memiliki sensitifitas $84 \%$, spesifisitas $89 \%$, nilai duga positif $87 \%$, nilai duga negatif 88\%.(Wiyono 2008).

Berdasarkan data cakupan dan hasil skrining telah dilakukan terhadap 904.099 orang $(2,45 \%)$, angka tersebut masih rendah sehingga memerlukan upaya lebih kuat untuk mencapai target yaitu 50\% perempuan usia 30-50 tahun selama 5 tahun. Sehingga Pemerintah melakukan optimalisasi program deteksi dini kanker serviks untuk periode 2015-2019. Kenyataannya, cakupan IVA di Indonesia masih jauh dari yang diharapkan. ${ }^{7}$

Beberapa faktor yang mempengaruhi seseorang melakukan tindakan pemeriksaan IVA salah satunya yaitu pengetahuan tentang IVA. Penyebab lain seperti keraguan akan pentingnya pemeriksaan, kurangnya pengetahuan, serta ketakutan merasa sakit pada saat pemeriksaan $^{8}$

Berdasarkan hasil penelitian R TSD dkk (2017) di Desa Cukir menunjukan bahwa ada hubungan antara pengetahuan dengan prilaku wanita usia subur tentang deteksi dini kanker serviks.Penelitian Sondang, dkk (2018) di Puskesmas Bondongan Bogor menyatakan tidak ada hubungan yang signifikan antara pengetahuan dengan perilaku WUS (30-50 tahun) dalam melakukan pemeriksaan IVA.

Berdasarkan tingkat pengetahuan seseorang dapat dilihat dalam Al Qur'an surat AlMujadalah: 11 yang artinya "Allah akan meninggikan orang-orang yang beriman diantaramu dan orang-orang yang diberi ilmu pengetahuan beberapaderajat dan Allah Maha mengetahui apa yang kamu kerjakan" (Q.S Al- Mujadalah: 11).

Kesadaran masyarakat Bantul untuk mendeteksi gejala kanker serviks masih sangat rendah. Hal ini diungkapkan oleh Kepala Dinas Kesehatan Kabupaten Bantul. Berdasarkan data dari Puskesmas se-Kabupaten Bantul, pada tahun 2018 terdapat 141.823 wanita usia subur. Namun, yang melakukan pemeriksakan IVA hanya 1.856 wanita usia subur. Meski begitu, angka tersebut masih sangat jauh dalam mencapai target deteksi dini metode IVA. ${ }^{9}$

Berdasarkan hasil studi pendahuluan yang dilakukan oleh peneliti di Puskesmas Bambanglipuro Bantul Yogyakarta pada tanggal 8 Oktober 2019, terdapat tiga Desa yang termasuk dalam cakupan wilayah kerja Puskesmas Bambanglipuro yaitu Desa Sidomulyo, Desa Mulyodadi dan Desa Sumbermulyo. Pada tahun 2018 tercatat sebanyak 188 wanita usia subur yang melakukan pemeriksaan IVA, yang terdiri dari 65 wanita usia subur warga Desa Sumbermulyo, 85 wanita usia subur warga Desa Mulyodadi dan 38 wanita usia subur warga Desa Sidomulyo. Sedangkan pada bulan Januari-September 2019 tercatat sebanyak 76 wanita usia subur yang melakukan pemeriksaan IVA, yang terdiri dari 36 wanita usia subur warga Desa Sumbermulyo, 23 wanita usia subur warga Desa Mulyodadi dan 17 wanita usia subur warga Desa Sidomulyo dari 82 wanita usia subur. Ini merupakan angka sangat kecil bila dilihat dari lingkup puskesmas yang mudah diakses. Selain itu, dilakukan pula wawancara singkat di Dusun Selo Desa Sidomulyo Bambanglipuro Bantul terhadap enam wanita usia subur yang sudah menikah. Pengetahuan mereka tentang IVA dan perilaku pemeriksaan IVA diperoleh hasil sebanyak tiga wanita usia subur tidak mengetahui akan pentingnya pemeriksaan IVA, menganggap tidak perlu dilakukan jika belum ada tanda-tanda gejala dari penyakitnya, sebanyak dua orang juga menyatakan bahwa dirinya sehat, tidak ada masalah pada organ reproduksinya, merasa malu dan takut kepada petugas kesehatan dengan tindakan pemeriksaan IVA sehingga tidak melakukan pemeriksaan IVA, dan sebanyak satu orang telah melakukan pemeriksaan IVA. Berdasarkan latar belakang diatas peneliti merasa perlu melakukan penelitian untuk mengetahui adanya hubungan tingkat pengetahuan tentang IVA dengan perilaku pemeriksaan IVA pada WUS Desa Sidomulyo Bambanglipuro Bantul. 


\section{METODE}

Penelitian ini dilakukan pada tanggal 7-13 Januari 2020. Penelitian ini deskriptif analitik dengan desain cross sectional. Populasi pada penelitian ini adalah semua wanita usia subur yang berada di Dusun Selo Desa Sidomulyo Bambanglipuro Bantul bulan Oktober 2019 yang berjumlah 82 wanita usia subur. Pengambilan sampel menggunakan teknik Purposive sampling dengan jumlah 50 wanita usia subur sesuai dengan kriteria inklusi dan kriteria eksklusi.

Pengumpulan data dilakukan dengan menggunakan instrument penelitian kuesioner.Analisis data yang dilakukan dalam penelitian ini terbagi atas analisa univariat dan bivariat dimana analisa univariat mendeskripsikan tentang karakteristik responden, tingkat pengetahuan dan perilaku pemeriksaan IVA. Analisa bivariat adalah menggambarkan suatu hubungan antara dua variabel, dimana dalam penelitian ini variabel bebas adalah tingkat pengetahuan tentang IVA dan variabel terikatnya perilaku pemeriksaan IVA. Analisis ini menggunakan uji korelasi Kendall-Tau.

Uji etik penelitian dilakukan di Komisi Etik Penelitian Kesehatan (KEPK) Universitas Respati Yogyakarta dengan nomor 388.3/FIKES/PL/XII/2019.Responden menyatakan kesediaan dan kesiapan untuk diambil datanya dan ikut serta dalam penelitian yang dilakukan.

\section{HASIL}

Tabel 1. Karakteristik, Tingkat Pengetahuan dan Perilaku Pemeriksaan IVA Wanita Usia Subur di Dusun Selo Desa Sidomulyo Bambanglipuro Bantul

\begin{tabular}{|c|c|c|c|}
\hline No & Karakteristik & Frekuensi & $\%$ \\
\hline \multirow[t]{5}{*}{1} & Umur & & \\
\hline & $15-19$ & 0 & 0.0 \\
\hline & $20-35$ & 31 & 62.0 \\
\hline & $36-49$ & 19 & 38.0 \\
\hline & Total & 50 & 100 \\
\hline \multirow[t]{6}{*}{2} & Pendidikan & & \\
\hline & SD & 5 & 10.0 \\
\hline & SMP & 12 & 24.0 \\
\hline & SMA & 25 & 50.0 \\
\hline & PT & 8 & 16.0 \\
\hline & Total & 50 & 100 \\
\hline \multirow[t]{6}{*}{3} & Pekerjaan & & \\
\hline & Ibu Rumah Tangga & 24 & 48.0 \\
\hline & Pedagang & 10 & 20.0 \\
\hline & PNS/Guru/Dosen & 4 & 8.0 \\
\hline & Karyawan Swasta & 12 & 24.0 \\
\hline & Total & 50 & 100 \\
\hline \multirow[t]{5}{*}{4} & Tingkat Pengetahuan & & \\
\hline & Baik & 15 & 30.0 \\
\hline & Cukup & 29 & 58.0 \\
\hline & Kurang & 6 & 12.0 \\
\hline & Total & 50 & 100 \\
\hline \multirow[t]{5}{*}{5} & Perilaku Pemeriksaan IVA & & \\
\hline & Baik & 10 & 20.0 \\
\hline & Cukup & 30 & 60.0 \\
\hline & Kurang & 10 & 20.0 \\
\hline & Total & 50 & 100 \\
\hline
\end{tabular}

Sumber : Data Primer 2020

Berdasarkan tabel 1 dapat dilihat bahwa sebagian besar responden memiliki umur 20-35 tahun sebanyak 31 responden (62.0\%), tingkat pendidikan SMA sebanyak 25 responden 
(50.0\%), pekerjaan ibu rumah tangga sebanyak 24 responden (48.0\%), tingkat pengetahuan cukup sebanyak 29 responden $(58.0 \%)$, dan perilaku cukup sebanyak 30 responden $(60.0 \%)$.

Tabel 2. Hasil uji korelasi kendall-tau Hubungan Tingkat Pengetahuan denganPerilaku Pemeriksaan IVA pada WUS di Dusun SeloDesa Sidomulyo Bambanglipuro Bantul

\begin{tabular}{lllll}
\hline & & & $\begin{array}{l}\text { Tingkat } \\
\text { Pengetahuan }\end{array}$ & $\begin{array}{l}\text { Perilaku Pemeriksaan } \\
\text { IVA }\end{array}$ \\
\hline Kendall's tau_b & Tingkat & Correlation & 1.000 & $.786^{* *}$ \\
& Pengetahuan & $\begin{array}{l}\text { Coefficient } \\
\text { Sig. (2-tailed) }\end{array}$ &. & .000 \\
& & $\mathrm{~N}$ & 50 & 50 \\
\hline & Perilaku & Correlation & $.786^{* *}$ & 1.000 \\
& Pemeriksaan & Coefficient & & \\
& IVA & Sig. (2-tailed) & .000 &. \\
& $\mathrm{~N}$ & 50 & 50 \\
\hline
\end{tabular}

Sumber : Data Primer 2020

Berdasarkan tabel 4.5 nilai korelasi Kendall Tau antara tingkat pengetahuan wanita usia subur dengan perilaku pemeriksaan IVA menunjukkan $p$ value $0,000(<0,01)$ dengan koefisien korelasi 0,786. Hal ini menunjukkan bahwa nilai $p$ value $<0,01$ maka Ha diterima dan Ho ditolak berarti terdapat hubungan antara tingkat pengetahuan dengan perilaku pemeriksaan IVA pada WUS di Dusun Selo Desa Sidomulyo Bambanglipuro Bantul. Berdasarkan keeratan hubungan antara kedua variabel dilihat dari angka koefisien korelasi yaitu 0,786 yang artinya memiliki hubungan positif atau searah, serta kedua variabel memiliki hubungan korelasi kuat dan terdapat tanda (**) yang menunjukkan bahwa adanya korelasi atau hubungan yang signifikan pada angka signifikasi sebesar 0,01 .

\section{PEMBAHASAN}

\section{Tingkat Pengetahuan Wanita Usia Subur}

Berdasarkan tabel 4 dapat dilihat bahwa tingkat pengetahuan wanita usia subur dalam kategori baik yaitu 15 responden (30\%), kategori cukup yaitu 29 responden (58\%), dan kategori kurang yaitu 6 responden (12\%). Hal ini menunjukkan bahwa mayoritas tingkat pengetahuan wanita usia subur di Dusun Selo Desa Sidomulyo Bambanglipuro Bantul dalam kategori pengetahuan cukup tentang Inspeksi Visual Asam Asetat, karena mampu menjawab pertanyaan kuesioner dengan tepat terkait pengertian IVA, syarat mengikuti IVA, dan metode pemeriksaan IVA. Hanya sebagian kecil yang belum mampu menjawab dengan tepat terkait waktu/jadwal pemeriksaan IVA dan keuntungan IVA, tentunya hal ini tidak akan terlepas dari faktor-faktor yang mempengaruhi pengetahuan.

Penelitian ini sejalan dengan penelitian yang dilakukan oleh Mirayashi (2014) yang menunjukkan bahwa sebagian besar responden berada dalam kategori tingkat pengetahuan sedang yaitu sebesar $47(53,4 \%)$ responden dari 88 responden.(10)Hal tersebut dapat diasumsikan bahwa wanita usia subur cukup mengetahui tentang inspeksi visual asam asetat (IVA). Hasil penelitian Sibero dan Hanum (2017) menunjukkan bahwa sebagian besar responden $(42,9 \%)$ dikategorikan berpengetahuan cukup. ${ }^{11}$

Penelitian yang telah dilakukan di Dusun Selo Desa Sidomulyo Bambanglipuro Bantul sebagian besar umur wanita subur berkisar antara 20-35 tahun sebanyak 31 responden (62\%). Hal ini sejalan dengan penelitian Pratondo, Rifa'i dan Kurdi (2017) yang menunjukkan bahwa sebagian besar responden sebanyak 15 responden (75\%) berumur 20 - 35 tahun, pada usia ini 
erat kaitannya dengan kejadian kanker servik. Dimana pada usia tersebut lebih resiko tinggi terkena penyakit menular.

Penelitian Farlikhatun, Sugiharto dan Anggraini (2018) menunjukkan bahwa faktor-faktor berhubungan dengan pengetahuan yaitu umur, pendidikan, pekerjaan dan sumber informasi.Responden penelitian ini dalam kategori cukup salah satunya dipengaruhi faktor umur. Menurut teori Hurlock (2010) menyatakan bahwa semakin cukup umur seseorang maka seseorang lebih dewasa dan tingkat kematangan dalam berfikir lebih tinggi, sedangkan dari segi kepercayaan, masyarakat akan lebih percaya pada orang yang sudah dewasa. Semakin bertambah usia semakin berkembang pula daya tangkap dan pola pikirnya. Sehingga dengan adanya pengetahuan yang cukup dan didasari oleh tingkat kematangan dalam berfikir, harapannya seseorang yang cukup umur akan melakukan pemeriksaan IVA dengan kesadaran sendiri sehingga deteksi dini kanker serviks dapat segera diketahui.

Berdasarkan karakteristik pendidikan responden, menunjukkan sebagian besar berpendidikan SMA sebanyak 25 responden (50\%). Penelitian Hanifah dan Fauziah (2019) menunjukkan bahwa sebagian besar responden berpendidikan menengah (SMA) yaitu 16 orang (48,5\%). ${ }^{12}$ Hal ini sejalan dengan penelitian Mirayashi (2014), mengatakan semakin tinggi tingkat pendidikan seseorang, semakin mudah seseorang tersebut menerima informasi sehingga banyak pula pengetahuan yang dimilikinya, demikian juga sebaliknya. Seseorang yang memiliki tingkat pendidikan yang tinggi cenderung mempunyai pola pikir yang lebih berkembang dan lebih logis. Tingkat pendidikan juga sangat berpengaruh terhadap pengetahuan dalam pembentukan perilaku seseorang.

Pekerjaan merupakan salah satu faktor yang mempengaruhi pengetahuan seseorang. Dari hasil penelitian menunjukkan bahwa sebagian responden bekerja sebagai ibu rumah tangga sebanyak 24 responden (48\%). Pekerjaan mempunyai peran dalam pengambilan keputusan. Hasil penelitian ini sejalan dengan penelitian Mirayasi (2014) di Pontianak yang menyebutkan bahwa $37,5 \%$ wanita yang melakukan deteksi dini kanker serviks merupakan ibu rumah tangga.

Hal ini tidak sesuai dengan teori Notoatmodjo (2010) yang menyatakan bahwa seseorang yang bekerja akan memiliki pengetahuan yang lebih luas dari pada seseorang yang tidak bekerja karena dengan bekerja seseorang akan banyak mendapat informasi dan pengalaman. Perbedaan antara hasil penelitian dengan teori kemungkinan disebabkan karena ibu rumah tangga memiliki waktu yang lebih banyak di rumah dan memiliki aktivitas sosial yang lebih tinggi serta sebagian orang cenderung mengikuti penyuluhan dan promosi kesehatan yang dilakukan oleh tenaga kesehatan.

Tingkat pengetahuan yang dimiliki seseorang dilatar belakangi oleh banyak faktor yang nantinya akan mempengaruhi kemampuan seseorang dalam memahami maupun meyakini suatu informasi yang didapat dan tentunya memiliki banyak aspek positif.

\section{Perilaku Pemeriksaan IVA}

Berdasarkan tabel 5 dapat dilihat bahwa tingkat perilaku pemeriksaan IVA dalam kategori baik yaitu 5 responden (10\%), kategori cukup yaitu 36 responden (72\%), dan dalam kategori kurang yaitu 9 responden (18\%). Hal ini menunjukkan bahwa mayoritas perilaku pemeriksaan wanita usia subur di Dusun Selo Desa Sidomulyo Bambanglipuro Bantul memiliki perilaku pemeriksaan IVA cukup, karena mampu menjawab pernyataan dengan tepat terkait pelaksanaan IVA, faktor penguat (petugas kesehatan), dan ketersediaan sarana dan prasarana. Hanya sebagian kecil yang belum mendapat dukungan dari suami/keluarga.

Berdasarkan data karakteristik responden, menunjukkan bahwa mayoritas usia berkisar antara 20-35 tahun sebanyak 31 responden (62\%). Semakin banyak usia seseorang maka semakin banyak pengalamannya, dan dari pengalaman tersebut dapat menjadikan acuan bagi 
seseoranguntuk berperilaku yang lebih baik. Sehingga seseorang yang memiliki pengalaman luas akan timbul kesadaran untuk melakukan pemeriksaan IVA guna mendeteksi dini kanker serviks.Hal ini sejalan dengan penelitian Pratondo, Rifa'i dan Kurdi (2017) yang mengatakan bahwa sebagian besar responden sebanyak 15 responden $(75 \%)$ berumur $20-35$ tahun melakukan pemeriksaan IVA. ${ }^{13}$

Selain usia, faktor yang mempengaruhi perilaku pemeriksaan IVA yaitu pendidikan. Berdasarkan hasil penelitian yang dilakukan menunjukkan bahwa mayoritas responden berpendidikan SMA sebanyak 25 responden (50\%). Seseorang dengan tingkat pendidikan menengah ke atas akan lebih mudah dalam memahami terkait masalah kesehatan. Dari tingkat pendidikan tersebut, pengetahuan yang diperoleh cenderung lebih tinggi dibandingkan dengan tingkat pendidikan yang rendah. Dengan adanya pemahaman tersebut, seseorang akan tahudan menunjukkan perilaku yang baik dalam menjaga kesehatan dan mencegah timbulnya penyakit. Hal tersebut menunjukkan bahwa pendidikan akan mempengaruhi perilaku seseorang termasuk perilaku akan pola hidup sehat serta berperan dalam pembangunan kesehatan (Nursalam \& Pariani, 2007).

Faktor selanjutnya yaitu pekerjaan. Hasil penelitian yang dilakukan menunjukkan bahwa mayoritas responden bekerja sebagai ibu rumah tangga sebanyak 24 responden (48\%). Hal ini dikarenakan ibu rumah tangga memiliki waktu luang dan kesempatan lebih banyak untuk mengikuti penyuluhan atau promosi kesehatan yang dilakukan oleh tenaga kesehatan dan melakukan pemeriksaan IVA dibandingkan dengan ibu yang bekerja. Hasil penelitian sejalan dengan penelitian Yuliwati (2012) di Kebumen menyebutkan bahwa 43,4\% wanita yang bekerja sebagai ibu rumah tangga melakukan pemeriksaan IVA. ${ }^{14}$

\section{Hubungan Tingkat Pengetahuan dengan Perilaku Pemeriksaan IVA}

Berdasarkan tabel 2 dapat dilihat bahwa nilai korelasi Kendall Tau antara tingkat pengetahuan wanita usia subur dengan perilaku pemeriksaan IVA menunjukkan $p$ value 0,000 $(<0,01)$ dengan koefisien korelasi 0,786 . Hal ini menunjukkan bahwa nilai $p$ value $<0,01$ maka Ha diterima dan Ho ditolak berarti terdapat hubungan antara tingkat pengetahuan dengan perilaku pemeriksaan IVA pada WUS di Dusun Selo Desa Sidomulyo Bambanglipuro Bantul. Berdasarkan keeratan hubungan antara kedua variabel dilihat dari angka koefisien korelasi yaitu 0,786 yang artinya memiliki hubungan positif atau searah, serta kedua variabel memiliki hubungan korelasi kuat dan terdapat tanda (**) yang menunjukkan bahwa adanya korelasi atau hubungan yang signifikan pada angka signifikasi sebesar 0,01.

Hal ini sejalan dengan penelitian Wulandari (2017) yang menunjukkan bahwa ada hubungan yang signifikan antara pengetahuan dengan perilaku ibu-ibu dengan melakukan IVA atau Pap Smear.(15) Penelitian Masturoh (2016) menunjukkan bahwa ada beberapa faktor yang berhubungan secara signifikan dengan perilaku wanita usia subur (WUS) dalam melakukan IVA yaitu pengetahuan, sikap, dukungan petugas kesehatan, akses informasi dan akses ke pelayanan kesehatan.(16) Hasil penelitian ini menunjukkan ada hubungan yang bermakna antara pengetahuan dengan deteksi dini kanker serviks di wilayah kerja Puskesmas Bangetayu Semarang.

Hasil penelitian Utami (2013) menunjukkan adanya hubungan yang signifikan antara pengetahuan dengan perilaku WUS dalam deteksi dini kanker serviks.(17) Penelitian Tiara (2013) mengatakan bahwa pengetahuan WUS tentang pemeriksaan IVA sangatlah penting, karena pengetahuan mempengaruhi perilaku kunjungan WUS dalam pemeriksaan IVA. Dengan pemeriksaan IVA yang sederhana diharapkan dapat menemukan lesi pra kanker secara dini sehingga angka kematian akibat kanker leher rahim dapat ditekan.

Hasil penelitian Masni, Riva'i dan Nurhapipa (2019) menunjukkan bahwa terdapat hubungan yang signifikan antara pengetahuan dengan perilaku wanita usia subur (WUS) 
dalam melakukan deteksi dini kanker rahim dengan metode IVA. Kemudian didukung dengan penelitian Novidasari dan Juhaeriah (2018) yang menunjukkan bahwa terdapat hubungan yang signifikan antara pengetahuan dengan perilaku deteksi dini kanker serviks metode IVA. ${ }^{18}$

Kurniawati (2015) dalam penelitiannya mengatakan bahwa ada hubungan bermakna antara pengetahuan wanita usia subur dengan pemeriksaan IVA.(19) Penelitian lainnya dilakukan oleh Lestari (2016) yang menyebutkan bahwa terdapat hubungan yang signifikan antara pengetahuan dengan deteksi dini kanker serviks.

Hasil penelitian ini tidak sejalan dengan penelitian yang dilakukan oleh Dewi (2014) yang menunjukkan tidak ada hubungan bermakna antara pengetahuan dengan perilaku WUS dalam deteksi kanker serviks dengan metode IVA. ${ }^{20}$

Peningkatan pengetahuan tidak akan selalu menyebabkan perubahan perilaku, namun memperlihatkan hubungan yang positif antara kedua variabel tersebut sehingga jika tingkat pengetahuannya tinggi maka perilakunya cenderung baik (Green, 1980). Pengetahuan yang tinggi tidak memastikan bahwa seseorang memiliki perilaku yang baik. Hal ini dikarenakan selain pengetahuan, masih terdapat beberapa faktor yang mempengaruhi perilaku diantaranya adalah kepercayaan, tersedia tidaknya fasilitas atau sarana kesehatan serta perilaku petugas kesehatan (Notoatmodjo, 2010).

Menurut peneliti, pengetahuan merupakan faktor yang mempengaruhi perilaku pemeriksaan IVA pada wanita usia subur. Dengan adanya pengetahuan yang baik, maka responden akan lebih mengenali tanda dan gejala penyakit kanker serviks, dan termotivasi untuk melakukan pemeriksaan IVA. Sehingga responden mengetahui sejak dini diagnosa yang terjadi dan mereka juga akan lebih memperhatikan kesehatan reproduksinya dan melakukan pengobatan lebih dini apabila mereka sudah terdiagnosa terkena kanker serviks. Untuk mendapatkan pengetahuan yang baik, maka wanita usia subur harus diajak berkerjasama dalam kegiatan puskesmas terutama kegitan yang menyangkut tentang pemeriksaan IVA.

Berdasarkan keeratan hubungan pada penelitian ini memiliki sifat korelasi yang positif (searah) dan kuat. Artinya pengetahuan wanita usia subur merupakan salah satu faktor yang memiliki nilai signifikan di Dusun Selo Desa Sidomulyo Bambanglipuro Bantul. Hal ini sesuai dengan teori Green dalam Notoatmodjo (2010) yang menyatakan bahwa faktor yang mempengaruhi perilaku pemeriksaan IVA diantaranya pengetahuan sikap, umur, pendidikan, pekerjaan dan dukungan orang yang berpengaruh.

Hasil penelitian ini sejalan dengan penelitian yang dilakukan oleh Siwi dan Trisnawati (2017) menyebutkan faktor-faktor yang mempengaruhi perilaku pemeriksaan IVA yaitu pendidikan dan pengetahuan tentang pemeriksaan IVA. ${ }^{21}$

\section{SIMPULAN}

Terdapat hubungan yang bermakna antara tingkat pengetahuan tentang IVA dengan perilaku pemeriksaan IVA pada WUS Desa Sidomulyo Bambanglipuro Bantul.

\section{SARAN}

Bagi Tenaga Kesehatan diharapkan dapat bekerjasama dengan institusi pendidikan guna memberikan penyuluhan kesehatan secara rutin kepada masyarakat khususnya tentang IVA tes. Bagi peneliti berikutnya diharapkan dapat melakukan penelitian terkait pemberian penyuluhan tentang IVA. 


\section{UCAPAN TERIMA KASIH}

Pada kesempatan ini peneliti mengucapkan banyak terimakasih kepada DR. Sri Handayani, S.Kep.,Ns.,M.Kes dan RR Viantika Kusumasari, S.Kep.,Ns.,M.Kep, Dian Nur Adkhana Sari, S.Kep.,Ns.,M.Kep, Endar Timiyatun, S.Kep.,Ns.,M.Kep, dan Eka Oktavianto, S.Kep.,Ns.,M.Kep atas bimbingannya. Kepala Desa Sidomulyo dan Kepala Dusun Selo Desa Sidomulyo Bambanglipuro Bantul yang telah memberikan izin tempat untuk melakukan penelitian.

\section{DAFTAR PUSTAKA}

1. WHO. Kasus Kanker Payudara Paling Banyak Terjadi di Indonesia. Databoks. 2019;

2. Globocan. The Global Cancer Observatory. Int Agency Res Cancer. 2019;

3. Riskesdas K. Hasil Utama Riset Kesehata Dasar (RISKESDAS). J Phys A Math Theor [Internet]. 2018;44(8):1-200. Available from: http://arxiv.org/abs/1011.1669\%0Ahttp://dx.doi.org/10.1088/17518113/44/8/085201\%0Ahttp://stacks.iop.org/17518121/44/i=8/a=085201?key=crossref.abc74c979a75846b3de48a5587bf708f

4. Dinas Kesehatan DIY. Profil Kesehatan D.I Yogyakarta tahun 2018. Profil Kesehat Drh Istimewa Yogyakarta tahun 2018 [Internet]. 2019;32. Available from: http://www.dinkes.jogjaprov.go.id/download/download/27.

5. Rasjidi I. Epidemiologi Kanker Serviks. Cancer. 2009;

6. Kemenkes RI. Kendalikan Kanker Servix Sejak Dini Dengan Imunisasi. Kementeri Kesehat RI. 2016;

7. Kementerian Kesehatan RI. Buletin Kanker. Pusat Data dan Informasi Kementrian Kesehatan RI 2015. Jakarta: Kemenkes RI;2015. Pencegah kanker leher rahim dan kanker payudara. 2009;

8. Nurani kurnia suci. Hubungan Pengetahuan Wanita Usia Subur Tentang Kanker Serviks Dengan Keikutsertaan IVA Test Di Puskesmas Umbulharjo II Yogyakarta. 2017;1-11.

9. Bantul DINKES. Narasi Profil Kesehatan 2019. 2019;1-47.

10. Mirayashi D. Hubungan Antara Tingkat Pengetahuan tentang Kanker Serviks dengan Keikutsertaan melakukan Pemeriksaan Inspeksi Visual Asetat di Puskesmas Alianyar Pontianak. 2014.

11. Sibero JT, Hanum R. Hubungan Pengetahuan Ibu Tentang Kanker Servik Dengan Pemeriksaan Iva Di Puskesmas Hamparan Perak Kabupaten Deli Serdang 2017. J Kesehat Almuslim. 2018;4(7):10-8.

12. Hanifah L, Fauziah AN. Hubungan Antara Pendidikan Dan Penghasilan Dengan Pengetahuan Wanita Usia Subur Tentang Iva Tes. J Kebidanan Indones J Indones Midwifery. 2019;10(1):114.

13. Pratondo, Rifa'i dan Kurdi.Hubungan Perilaku Pemeriksaan Inspeksi Visual Asam Asetat ( IVA ) Dengan Kejadian Kanker Cervik Pada Wanita Usia Subur ( Relationship Between of Behavior Investigation Visual Acid Assets Inspection ( IVA ) With Cervic Cancer Cause In Women Age ) Wempy R . 2017;3(2).

14. Yuliwati. Faktor-faktor yang Berhubungan dengan Perilaku WUS dalam Deteksi Dini Kanker Leher Rahim Metode IVA di Wilayah Puskesmas Prembin Kabupaten Kebumen Tahun 2012. 2012;hal: 71. Available from: http://lib.ui.ac.id/file?file=digital/20318324S-Yuliwati.pdf

15. Wulandari. Dengan Perilaku Melakukan Iva Atau Pap Smear Pada Ibu-Ibu Usia 25-50 Tahun Di Dusun Greges Donotirto Kretek. 2017;

16. Masturoh E. Faktor - Faktor yang Mempengaruhi Wanita Usia Subur (WUS) dalam Melakukan Deteksi Dini Kanker Serviks Metode Inspeksi Visual Asam Asetat (IVA). 
Universitas Negeri Semarang. 2016.

17. Utami NM. Knowledge Level Relationship With Fertile Age Couple Of Conduct Cervical Cancer Early Detection Of Public Health In The Market District Sangkrah Pasar Kliwon Surakarta. 2013;3.

18. Novidasari S, Juhaeriah J. Faktor Yang Berhubungan Dengan Perilaku Deteksi Dini Kanker Serviks Metode Inspeksi Visual Asam Asetat ( IVA ) Pada Wanita Usia Subur Di Wilayah Kerja Puskesmas Cimahi Tengah Tahun 2018 Upaya deteksi dini kanker serviks di Penyelenggara Jaminan Sosial ( B. Pinlitamas 1. 2018;1(1):359-71.

19. Kurniawati I. Pengaruh Pengetahuan, Motivasi dan Dukungan Suami Terhadap Perilaku Pemeriksaan Iva Pada Kelompok Wanita Usia Subur di Puskesmas Kedungrejo. Journal of applied microbiology. 2015.

20. Dewi L. Faktor-Faktor Yang Berhubungan Dengan Perilaku Wanita Usia Subur Dalam Deteksi Dini Kanker Serviks Dengan Metode Pemeriksaan Inspeksi Visual Asam Asetat (IVA) Di Wilayah Kerja Puskesmas Tanjung Hulu Pontianak Timur Tahun 2014. J PRONERS. 2014;1(1):1-10.

21. Siwi RPY. Faktor-faktor yang Mempengaruhi Perilaku Pemeriksaan IVA (Inspeksi Visual Asam Asetat) dalam Deteksi Dini Kanker Serviks pada Pasangan Usia Subur. Glob Heal Sci [Internet]. 2017;2(3):220-5. Available from: http://jurnal.csdforum.com/index.php/ghs 